\title{
Prediction of tunnel boring machine penetration rate using ant colony optimization, bee colony optimization and the particle swarm optimization, case study: Sabzkooh water conveyance tunnel
}

\author{
Alireza Afradi ${ }^{1 \otimes(\bullet)}$, Arash Ebrahimabadi ${ }^{*} \otimes(\mathbb{0})$, Tahereh Hallajian ${ }^{1 \otimes(0)}$ \\ ${ }^{1}$ Department of Mining and Geology, Qaemshahr Branch, Islamic Azad University, Qaemshahr, 4765161964, Iran \\ *Corresponding author: e-mail A.Ebrahimabadi@Qaemiau.ac.ir, tel. +981142155025
}

\begin{abstract}
Purpose. The purpose of this study is to use a novel approach to estimate the tunnel boring machine (TBM) penetration rate in diverse ground conditions.

Methods. The methods used in this study include ant colony optimization (ACO), bee colony optimization (BCO) and the particle swarm optimization (PSO). Moreover, a comprehensive database was created based on machine performance using penetration rate $(\mathrm{m} / \mathrm{h})$ as an output parameter - as well as intact rock and rock mass parameters including uniaxial compressive strength (UCS) (MPa), Brazilian tensile strength (BTS) (MPa), rock quality designation (RQD) (\%), cohesion (MPa), elasticity modulus (GPa), Poisson's ratio, density $\left(\mathrm{g} / \mathrm{cm}^{3}\right)$, joint angle (deg.) and joint spacing (m) as input parameters.

Findings. Results showed that the analyses yielded several realistic and reliable models for predicting penetration rate of TBMs. ACO model has $R^{2}=0.8830$ and RMSE $=0.6955$, BCO model has $R^{2}=0.9367$ and RMSE $=0.5113$ and PSO model has $R^{2}=0.9717$ and $\mathrm{RMSE}=0.3418$.
\end{abstract}

Originality. Prediction of TBM penetration rate using these methods has been carried out in the Sabzkooh water conveyance tunnel for the first time.

Practical implications. According to the results, all three approaches are very effective but PSO yields more precise and realistic findings than other methods.

Keywords: tunnel boring machine, penetration rate, Sabzkooh water conveyance tunnel, ant colony optimization, bee colony optimization, particle swarm optimization

\section{Introduction}

Today, in many major cities around the world, urban transport tunnels play an important role in human life, requiring the use of advanced modern tools such as tunneling machines (TBMs) for excavating and carrying out these projects [1], [2]. The speed and quality of excavating have made these machines competitive with traditional methods [3], [4]. Predicting the performance of TBM is one of the crucial issues in estimating the cost of construction and execution of tunnel projects. TBM performance is highly depen-dent on the rate of penetration of the device and penetration rate is one of the important factors the excavating rate or advance rate of TBM [5], [6].

The penetration rate is a function of rock and machine properties [7]. The penetration rate is defined as the ratio of excavating distance to excavating time during a continuous excavating phase [8], [9]. TBM penetration rate estimates can be used to reduce the risks associated with the costs of current investment in excavating operations [10], [11]. Estimating the penetration rate has a great impact on controlling the project time and choosing the excavating method [12], [13]. However, TBMs are susceptible to geological conditions such as fractures, cracks and swelling and rock explosions [14], [15]. The relationship between penetration rate and rock parameters has been investigated by some researchers [16]-[23] and some have suggested using a rock mass classification to estimate the performance of TBMs [24]-[30]. Penetration rate prediction models used in engineering can be divided into three categories:

1) experimental models;

2) theoretical models;

3) numerical models.

Experimental models are often obtained by analyzing data from tunnel projects [31], [32], while theoretical models are obtained by performing laboratory tests and simulating reality in laboratories [33]-[35]. Recently, highly regarded numerical models are a new and less expensive method that reflects reality using project records [36]-[42]. In this study, ant colony optimization (ACO), bee colony optimization (BCO) and the particle swarm optimization (PSO) were used to predict TBM penetration rate in Sabzkooh water conveyance tunnel. 


\section{Materials and methods}

\subsection{Sabzkooh water conveyance tunnel}

Sabzkooh water conveyance tunnel with an approximate length of 10700 meters and an excavating diameter of 4.5 meters has been designed to transfer water from Sabzkooh Basin to Choghakhor Dam in Chaharmahal and Bakhtiari Province, about $80 \mathrm{~km}$ south of Shahrekord. Location of the Sabzkooh water conveyance tunnel, $\phi s$ can be seen in Figure1.

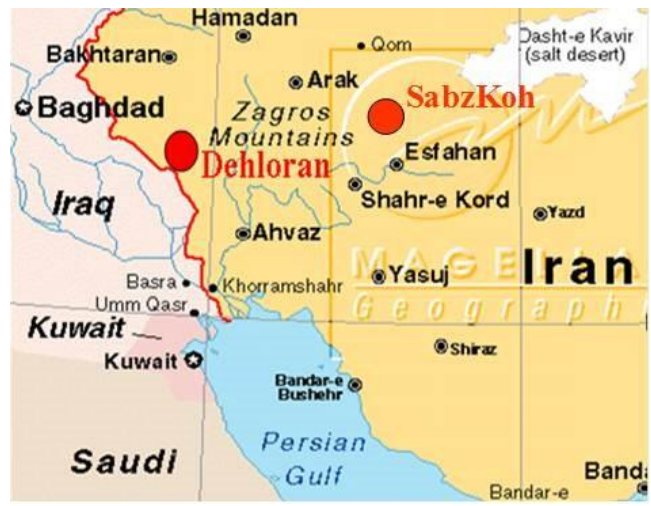

Figure 1. Location of the Sabzkooh water conveyance tunnel

\subsection{Ant colony optimization (ACO)}

This method is inspired by the ability of ants to find the shortest path between a nest and a food source. As the ants move around, they leave a chemical called pheromone. When a population of ants traverses several paths between a nest and a food source, it is observed after a certain time that the number of pheromones left in the different paths varies. This is due to the fact that ants traveling the shorter route have more traffic due to the shorter route in a given period of time. Because the ants inherently choose the route that It has more pheromones, so it will be a while that the ants have chosen the shorter route. Using the ant's method, a search method is implemented that uses every step of the information from the previous steps to reach the goal. The ant colony algorithm is inspired by studies and observations on ant colonies.

These studies have shown that ants are social insects that live in colonies, and their behavior is more for the survival of the colonies than for the survival of a component. One of the most important ants of ants is their behavior in finding food, and in particular how to find the shortest route between food sources and nests. This kind of ant's behavior has a kind of mass intelligence that has been the focus of scientists recently in the real world. They then return to the nest and leave a trail of Pheromone. Such rows turn white after rain and are visible. Other ants, when they find this path, sometimes give up roaming and follow it. Then, if they get food, they return home and leave another trail beside the previous one; in other words, they reinforce the previous route. The pheromone evaporates over time, which is useful in three ways, making it less attractive to subsequent ants. As an ant travels and reinforces shorter paths in the long run, each path between the house and the food that is shorter (better) is further strengthened and the farther away the less, and if the pheromone does not evaporate, the paths that have been repeated several times. They were so overwhelming that they limited the random search for food. Another advantage is that it stays off when the food ends at an attractive route.
The problem is finding the shortest path and solving these artificial ants. The ant colony algorithm, or in fact "ant colony optimization" as the name implies, is based on the natural behavior of the ant colonies and the working ant. The process of finding food in the ant colony is very optimistic. When ants begin their exploration of food sources, they will naturally find a "logical" and "optimal" route from their nest to food sources. In other words, the ant population is always able to find an optimal route to supply the food they need. Simulating such optimal behavior forms the basis of ant colony optimization. In this article, the ant colony algorithm is fully described. It should be noted that the exact name of this algorithm is ant colony optimization, which is often referred to as the ant algorithm or ant colony algorithm [43]. Imagine two ants moving from a nest to a food source through two completely different paths. As they move toward the food source, the ants release a trace of pheromone into the environment that disintegrates naturally over time.

In this case, on the way back to the nest, the ant will start releasing pheromones back into the environment, thereby strengthening the pheromone trace left in the shortest path. Other ants instinctively follow the strongest pheromone pathway in the environment and reinforce the pheromone pathway in this pathway. After a certain period of time, not only does the pheromone trace in the shortest path not collapse, but it is further enhanced by the accumulation of other pheromone traces. The pathway where the strongest pheromone trace is left becomes the default path for ants to move from a colon to a food source and vice versa. The algorithms derived from the ant colony algorithm are a subset of swarm intelligence methods. These are the types of research and study areas that study algorithms inspired by the concept of "swarm behaviors". Swarm intelligence algorithms consist of a set of simple individual entities that interact with one another through "self-organizing". Self-organization means the absence of a centralized control system to control and coordinate the members of a crowded intelligence system.

One of the algorithms used in this study is an ant colony optimization algorithm for continuous domains [44]. For the continuous optimization problem, a model can be formulated as $P=(S \Omega \cdot f)$, where $S$ defines all finite sets of discrete decision variables, $\Omega$ defines constraints between variables and a target function $(f: S \rightarrow R 0+)$ which must be minimized or maximized [43], [45]. It should be noted that in ant colony optimization, the basis of work is the gradual construction of solutions based on the probability of solution components and the probability values are calculated based on the pheromone values of each component [46], [47]. In ant colony optimization implemented in hybrid optimization problems, a set of parts related to the solution available is defined by the problem formula [48]. At each step of the construction, the ants make a possible selection of $c i$ from $N\left(s^{p}\right)$ by Equation (1):

$$
p\left(c_{i j} \mid s^{p}\right)=c_{i j}^{p} \cdot \frac{\eta(c i j)^{\beta}}{\sum c_{i l} \in N\left(s^{p}\right)^{\tau i j \alpha} \cdot \eta(c i j)^{\beta}} \cdot \forall c_{i j} \in N\left(s^{p}\right),
$$

where:

$i j$ - the amount of pheromone linked to $c i j$;

$\eta(0)$ - a weight function that assigns an innovative value to $c_{i l} \in N\left(s^{p}\right)$ at each step of making a value.

The values determined by the weighting function are often referred to as apocalyptic information [49]. In addition, $\alpha$ 
and $\beta$ are positive parameters which values determine the relationship between pheromone information and heuristic information. For sampling and solution, we define a Gaussian kernel as the sum of the weights of several onedimensional Gaussian functions which are called $G^{i}(x)$ :

$$
G^{i}(x)=\sum_{l=1}^{k} \omega_{l} g_{l}^{i}(x)=\sum_{l=1}^{k} \omega_{l} \frac{1}{\sigma_{l}^{i} \sqrt{2 \pi}} e^{-\frac{\left(x-\mu_{l}^{i}\right)^{2}}{2 \sigma_{l}^{i^{2}}}} .
$$

When multi-core probability density functions are used, the dimension of problem $(i=1 \ldots n)$ determines a single probability density function. $G^{i}(x)$ is represented by three parametric vectors where $\omega$ is vector of the weights associated with any Gaussian function, $\mu^{i}$ is middle vector, $\delta^{i}$ is standard deviation vector and $g_{l}^{i}(x)$ is one-dimensional Gaussian functions. The cardinal of all these vectors is equal to the number of Gaussian functions of the Gaussian kernel. For ease of use, $k$ is used to describe it. Therefore:

$|\omega|=\left|\mu^{i}\right|=\left|\delta^{i}\right|=k$.

As such, the probability density function creates a simple and logical sampling and provides greater flexibility than the single Gaussian function.

\subsection{Bee colony optimization (BCO)}

The bees of a beehive can spread for miles around the hive and search for and collect nectar. Of course, in this area, nectar is only available in some places and in varying amounts. The difference in the amount of nectar available at each location requires a certain number of bees to collect nectar given these values. Watch bees are tasked with searching for a new nectar source (nectar). The process of searching for a colony's food (a bee hive collection) is initiated by watch bees that are sent to search for rich moths. Watch bees randomly move from one flower to another.

Upon returning to a part of the hive as a showroom, these bees watch the other bees in a rotating motion to inform the three main features of the new beehives: distance, direction, amount. A factor such as the amount of nectar compared to other areas determines the number of bees assigned to this nectar site. In parallel, worker bees returning from other moths and collecting nectar at the spot inform other bees about the amount of nectar remaining in their area. This news can have three different reactions. First, this place needs more worker bees. Second, the number of working bees present at this site is sufficient. Third, the bees in this area should be reduced and moved to another location. All of the above-mentioned steps include what happens at any moment in a hive. Inspired by humans today, this process has led to a model called the bee algorithm that moves the search for the best answer.

This algorithm is one of the best algorithms ever presented. Because of its high flexibility in obtaining various functions, whether it is a smooth slope function or a high roughness slope function. The algorithm builds on the bee's collective life and finding high quality flower gardens and high nectar value for bees [50]. As the bees first look for high quality flowerbeds, after finding the flowerbeds, they bring information about the flowerbeds to the hive, then, with the information that the bees have brought to the hive, take some of the bees with them to the location of the flowerbed and around it. To find a better one, in proportion to the quality of the flowers found, search for more bees around it and continue this process to find the best and most optimal. This algorithm is based on the behavior of the bees to find the appropriate flower for gathering nectar [51]. Bee algorithm is one of the algorithms based on collective intelligence and the result of the relationship of bees with each other [52].

In this algorithm, each bee alone is not able to find the right flower, collaboration and information exchange between a set of bees for finding the right flower [49]. In the bee algorithm, the bee community and colony consist of three groups: hired bees, search bees, and watch bees [53]. In this algorithm, each food source represents a possible solution to the optimization problem, and the amount of nectar in each source indicates the quality of that resource [50]. In the first stage, produce an initial population of answers equal to the position of the food source, where indicates the number of bees employed or searchers. Each answer $(j=1.2 .3 \ldots . . S N)$ is a $\mathrm{D}$ vector, where $\mathrm{D}$ is the number of optimization parameters. Searcher bees select a food source. This choice is influenced by the quality of the food source. The probability of choosing each source is calculated by Equation (4):

$$
P_{i}=\frac{\mathrm{fit}_{i}}{\sum_{N-1}^{S N} \mathrm{fit}_{N}},
$$

where:

$f_{i t}-$ fit value of $i$.

Selection of the new food source $(V i j)$ is made by Equation (5), according to the previous food source $(X i j)$ :

$V i j=X i j+(X i j-X k j)$,

where:

$j \epsilon\{1.2 \ldots S N\}$ and $k \epsilon\{1.2 \ldots S N\}$ random indicators are selected. Although $k$ is selected at random, it must be different from $j$. In the bee algorithm, if a food source does not recover after a certain iteration, it is called that abandoned food source. In this case, the bees watch according to Equation (6) and they will randomly replace a new food source:

$$
X_{i}^{j}=X_{\min }^{i}+\operatorname{rand}[0.1]\left(X_{\max }^{j}-X_{\min }^{j}\right),
$$

where:

$$
j \text { - equal to the number of optimization variables. }
$$

\subsection{Particle swarm optimization (PSO)}

In engineering and management sciences, optimization means achieving an optimal state of production with the lowest possible cost and maximum path efficiency. In programming and mathematics, optimization is defined as the process by which the selection and design of data structures and the appropriate algorithms and instructions will produce the most efficient applications. The PSO algorithm, which stands for particle swarm optimization means cumulative particle optimization. The PSO algorithm is the most optimized algorithm with regard to the behaviors that govern the life of birds and creatures. Experimental studies have shown that the redshift of each particle is due to the flight pattern of the neighboring particles, and the pattern of each particle is modeled to one side and then optimized. In general, optimization is the process of making something better, or in other words, optimizing the inputs of a device that we want to achieve the least or maximum result with our mathematical 
tests and processes. An aggregate particle optimization algorithm starts with a group of random agents and then searches for the optimal ones with updated products. Each particle is treated as a point in the desired space, which is adjusted according to its own motion experiences as well as those of other particle motions. That particle is obtained. Other parameters that are important in this algorithm are:

- every particle is looking for the best spot;

- each particle is moving (otherwise it cannot search);

- so, due to the movement of the particle, it has speed;

- this algorithm works based on particle motion and intelligence;

- in this algorithm the concept of social interaction is used to solve and optimize;

- the particles are in the search for a permanent solution space and remember the situation where it worked best.

In this model, simple behaviors to find the nearest neighbors are adjusted for pedestrians. This model of birds or fish are randomly placed in a pixel table search space, with each replication the nearest neighbor chosen and the velocity of the node replaced by the nearest neighbor. This allows the group to quickly converge in an indefinable direction without change. To solve this problem, a component of insanity was used as a random change in groups. To further develop this model, the notion of birds or fish was added to the model as a memory of the best positions of each member and its neighbors. The best previous position of any member is the best position that member has ever had since his or her life. Best Neighborhood is the best situation met by a member's neighbors.

These two best positions act as attraction points. The group members' positions can be updated using a set of simple rules. This allows the member to move toward one of the two better positions. Over time, the members of the algorithm gather around a target by repeating the algorithm. This behavior was effective even without the coordination of speed and factor of madness. The final model is called particle group optimization. The PSO algorithm is a social search algorithm that is modeled on the behavior of a group of birds and fish [54]. In PSO algorithm, the particles flow in the search space. Changing the status of particles is based on their own experience and knowledge of other particles [55]. The result of modeling of social behavior is the search process that particles tend to better position [56].

In the first step, we quantify the particle to obtain the response [57]. After quantification, in the second step, the particles are evaluated for their suitability and value [58]. In the third step, considering the location of each particle in the group and the best global location, the particles are compared to determine the best value of each particle and the best global value within the group in terms of the target [59]. In the next step, if we reach the right criterion, then the search is over and we get the answer. Otherwise the particles will be updated again in terms of their speed and location and their previous speed and location, and again the particle of step two. The cycle begins to continue until it reaches the appropriate criterion for stopping [60]. The new position and velocity of each particle changes as follows:

$$
\begin{aligned}
& V(t+1)=w V_{i}(t)+C_{1} r_{1}\left(p_{-} \text {best }-x_{i(t)}\right)+ \\
& +C_{2} r_{2}\left(g_{-} \text {best }-x_{i(t)}\right)
\end{aligned}
$$

$$
X_{i(t+1)}=X_{i(t)}+V_{i(t+1)},
$$

where:

$V_{i}(t+1)$ - the particle velocity $i$ in the new iteration;

$V i(t)$ - the velocity of the particle $i$ in the previous iteration;

$p \_b e s t(i)$ - the best position that particle $i$ has ever had;

$X_{i}(t)$ - the current position of the particle;

$X_{i}(t+1)$ - the current position of the particle in the new iteration;

$g \_$best $(i)$ - the best position of the best particle (the best position all particles have ever had);

$r_{1}, r_{2}$ - two random numbers between zero and one that are used to maintain group diversity;

$C_{1}, C_{2}$ - the cognitive and social parameters, respectively. Selecting the appropriate value for these parameters results in accelerating algorithm convergence and preventing premature convergence in local optimization. Recent research shows that choosing a larger value for the cognitive parameters. $\mathrm{w}$ is the weighted inertia, which is used to guarantee the convergence of the particle. Weight inertia is used to control the effect of past speed records on current speeds. The basis of PSO's work is each particle adjusts to best location and the total location of neighbors.

\subsection{Data analysis}

By examining each of the parameters in the mathematics calculation, it can be said that all the parameters show their maximum correlation with the penetration rate when the equation between them is power and Linear. Hence the equation is chosen on this basis. In this study, we consider an equation that has been investigated using all three algorithms. In this study, we divide the tunnel into four phases (P1, P2, P3, P4). The descriptive statistic of database for Sabzkooh water conveyance tunnel presented in Table 1. The equation chosen in this study as follows:

$$
\begin{aligned}
& P R=W 1 . U C S+B T S^{W 2}+W 3 \cdot R Q D+C^{W 4}+ \\
& +W 5 . E+P^{W 6}+W 7 . D+W 8 . J A+J S^{W 9} .
\end{aligned}
$$

\section{The result of modeling}

\subsection{Results of ant colony optimization (ACO)}

In models 1-4 for ant algorithm, the generated dataset is separated into 4 steps, and then each step is employed to test targets while the other steps are employed to train sets. In model 5, 100\% of the dataset was employed to train and then each step of the dataset (P1-P4) was employed for testing for the various models. Finally, model 6 was improved using $85 \%$ of training dataset and $15 \%$ of testing dataset for ant algorithm. Our result is that model 6 and its attained equation are sufficient accurate, since the prediction of penetration rate for ant algorithm is $R^{2}=0.8830$ and RMSE $=0.6955$ of best model in the Sabzkooh water conveyance tunnel. Coefficient of determination $\left(R^{2}\right)$, RMSE and coefficient of weighting of the ant algorithm for prediction of TBM penetration rate in the Sabzkooh water conveyance tunnel for all models are shown in Table 2. The distribution chart and the matching chart of the measured values of penetration rate or target and the predicted penetration rate values by the prediction model of the top model are shown in Figures 2 and 3, respectively. Also, the equation obtained using ACO described in Equation (10). 
Table 1. Descriptive statistic of database for Sabzkooh water conveyance tunnel

\begin{tabular}{|c|c|c|c|c|c|c|c|c|c|c|}
\hline & $\begin{array}{c}\text { Uniaxial } \\
\text { compressive } \\
\text { strength } \\
\text { (UCS), MPa }\end{array}$ & $\begin{array}{c}\text { Brazilian } \\
\text { tensile } \\
\text { strength } \\
\text { (BTS), } \\
\text { MPa }\end{array}$ & $\begin{array}{c}\text { Rock } \\
\text { quality } \\
\text { designation } \\
\text { (RQD), \% }\end{array}$ & $\begin{array}{l}\text { Cohesion, } \\
\mathrm{MPa}\end{array}$ & $\begin{array}{l}\text { Elasticity } \\
\text { modulus, } \\
\text { GPa }\end{array}$ & $\begin{array}{l}\text { Poisson's } \\
\text { ratio }\end{array}$ & $\begin{array}{l}\text { Density, } \\
\mathrm{g} / \mathrm{cm}^{3}\end{array}$ & $\begin{array}{l}\text { Joint angle, } \\
\text { deg. }\end{array}$ & $\begin{array}{c}\text { Joint spacing, } \\
\text { m }\end{array}$ & $\begin{array}{l}\text { Penetration } \\
\text { rate, } \mathrm{m} / \mathrm{hr}\end{array}$ \\
\hline Mean & 29.9143 & 9.0483 & 44.87 & 1.5305 & 7.6068 & 0.2817 & 2.5015 & 32.96 & 0.937 & 7.5970 \\
\hline $\mathrm{N}$ & 99 & 99 & 99 & 99 & 99 & 99 & 99 & 99 & 99 & 99 \\
\hline Std. deviation & 19.14683 & 2.57292 & 15.107 & 1.10036 & 5.08426 & 0.05129 & 0.10905 & 6.838 & 0.3996 & 2.02355 \\
\hline Minimum & 9.49 & 5.00 & 20 & 0.25 & 0.85 & 0.20 & 2.30 & 21 & 0.3 & 4.35 \\
\hline Maximum & 70.00 & 15.00 & 67 & 3.73 & 18.92 & 0.36 & 2.70 & 45 & 1.6 & 11.37 \\
\hline Variance & 366.601 & 6.620 & 228.217 & 1.211 & 25.850 & 0.003 & 0.012 & 46.753 & 0.160 & 4.095 \\
\hline Harmonic mean & 20.3616 & 8.4174 & 38.22 & 0.7714 & 3.7956 & 0.2727 & 2.4968 & 31.43 & 0.746 & 7.0576 \\
\hline Geometric mean & 24.4594 & 8.7174 & 41.78 & 1.1124 & 5.7157 & 0.2771 & 2.4992 & 32.21 & 0.843 & 7.3261 \\
\hline Std. error of mean & 1.92433 & 0.25859 & 1.518 & 0.11059 & 0.51099 & 0.00515 & 0.01096 & 0.687 & 0.0402 & 0.20337 \\
\hline
\end{tabular}

Table 2. Ant algorithm results for six various models

\begin{tabular}{|c|c|c|c|c|c|c|c|c|c|c|c|c|c|}
\hline \multirow[b]{2}{*}{ Model } & \multirow[b]{2}{*}{$\begin{array}{c}\text { Training } \\
\text { dataset }\end{array}$} & \multirow[b]{2}{*}{$\begin{array}{l}\text { Testing } \\
\text { dataset }\end{array}$} & \multicolumn{9}{|c|}{ Coefficient of weighting } & \multicolumn{2}{|c|}{ Model evaluation } \\
\hline & & & $\begin{array}{l}\text { W1 } \\
\text { UCS }\end{array}$ & $\begin{array}{l}\text { W2 } \\
\text { BTS }\end{array}$ & $\begin{array}{c}\text { W3 } \\
\text { RQD }\end{array}$ & $\begin{array}{c}\text { W4 } \\
\text { Cohesion }\end{array}$ & $\begin{array}{c}\text { W5 } \\
\text { Elasticity } \\
\text { modulus }\end{array}$ & $\begin{array}{c}\text { W6 } \\
\text { Poisson's } \\
\text { ratio }\end{array}$ & $\begin{array}{c}\text { W7 } \\
\text { Density }\end{array}$ & $\begin{array}{c}\text { W8 } \\
\text { Joint } \\
\text { angle }\end{array}$ & $\begin{array}{c}\text { W9 } \\
\text { Joint } \\
\text { spacing }\end{array}$ & $R^{2}$ & RMSE \\
\hline 1 & P2-P3-P4 & P1 & -0.0028 & 0.0319 & -0.2090 & 0.6234 & -1.9245 & 0.9555 & -2.1324 & -0.2305 & 2.9876 & 0.8211 & 0.8321 \\
\hline 2 & P1-P3-P4 & $\mathrm{P} 2$ & -0.0023 & 0.0237 & -0.3118 & 0.5228 & -1.7243 & 0.9339 & -1.7654 & -0.2977 & 2.8765 & 0.8422 & 0.7814 \\
\hline 3 & P1-P2-P4 & P3 & -0.0030 & 0.0252 & -0.3020 & 0.4620 & -1.8133 & 0.9876 & -2.3145 & -0.2140 & 2.4612 & 0.8021 & 0.9134 \\
\hline 4 & P1-P2-P3 & $\mathrm{P} 4$ & -0.0039 & 0.0262 & -0.3131 & 0.5918 & $1.9776-$ & 0.9111 & -1.9970 & -0.2906 & 2.5543 & 0.8334 & 0.7987 \\
\hline \multirow{4}{*}{5} & \multirow{4}{*}{$\begin{array}{l}100 \% \\
\text { of dataset } \\
\text { used for } \\
\text { training in } \\
\text { the model }\end{array}$} & $\mathrm{P} 1$ & -0.0034 & 0.0259 & -0.3122 & 0.4865 & -1.6234 & 0.9075 & -1.7643 & -0.1861 & 2.6543 & 0.7986 & 0.9543 \\
\hline & & $\mathrm{P} 2$ & -0.0034 & 0.0259 & -0.3122 & 0.4865 & -1.6234 & 0.9075 & -1.7643 & -0.1861 & 2.6543 & 0.8654 & 0.7865 \\
\hline & & P3 & -0.0034 & 0.0259 & -0.3122 & 0.4865 & -1.6234 & 0.9075 & -1.7643 & -0.1861 & 2.6543 & 0.8532 & 0.8123 \\
\hline & & $\mathrm{P} 4$ & -0.0034 & 0.0259 & -0.3122 & 0.4865 & -1.6234 & 0.9075 & -1.7643 & -0.1861 & 2.6543 & 0.8421 & 0.8234 \\
\hline 6 & $\begin{array}{c}85 \% \\
\text { of all } \\
\text { dataset }\end{array}$ & $\begin{array}{c}15 \% \\
\text { of all } \\
\text { dataset }\end{array}$ & -0.0025 & 0.0209 & -0.3927 & 0.3754 & -1.4123 & 0.8865 & -1.5321 & -0.2897 & 2.5411 & 0.8830 & 0.6955 \\
\hline
\end{tabular}

$P R=-0.0025 . U C S+B T S^{0.0209}-0.3927 . R Q D+C^{0.3754}-1.4123 . E+P^{0.8865}-1.5321 . D-0.2897 . J A+J S^{2.5411}$.

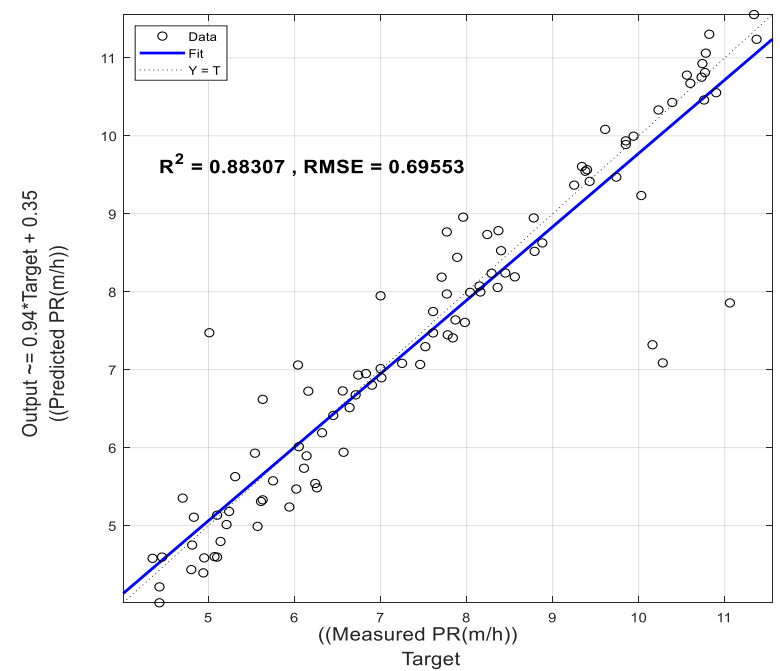

Figure 2. The distribution chart of the measured values of penetration rate or target and the predicted penetration rate values by the prediction model of the top model using ACO

\subsection{Results of bee colony optimization (BCO)}

In models 1-4 for bee algorithm, the generated dataset is separated into 4 steps, and then each step is employed to test targets while the other steps are employed to train sets. In model $5,100 \%$ of the dataset was employed to train and then each step of the dataset (P1-P4) was employed for testing for the various models. Finally, model 6 was improved using
$85 \%$ of training dataset and $15 \%$ of testing dataset for bee algorithm. Our result is that model 6 and its attained equation are sufficient accurate, since the prediction of penetration rate for bee algorithm is $R^{2}=0.9367$ and $\mathrm{RMSE}=0.5113$ of best model in the Sabzkooh water conveyance tunnel. Coefficient of determination $\left(R^{2}\right)$, RMSE and coefficient of weighting of the bee algorithm for prediction of TBM penetration rate in the Sabzkooh water conveyance tunnel for all models are shown in Table 3. The distribution chart and the matching chart of the measured values of penetration rate or target and the predicted penetration rate values by the prediction model of the top model are shown in Figures 4 and 5, respectively. Also, the equation obtained using $\mathrm{BCO}$ described in Equation (11).

\subsection{Results of bee colony optimization (BCO)}

In models 1-4 for PSO algorithm, the generated dataset is separated into 4 steps, and then each step is employed to test targets while the other steps are employed to train sets. In model 5, 100\% of the dataset was employed to train and then each step of the dataset (P1-P4) was employed for testing for the various models. Finally, model 6 was improved using $85 \%$ of training dataset and $15 \%$ of testing dataset for PSO algorithm. Our result is that Model 6 and its attained equation are sufficient accurate, since the prediction of penetration rate for bee algorithm is $R^{2}=0.9717$ and $\mathrm{RMSE}=0.3418$ of best model in the Sabzkooh water conveyance tunnel. 


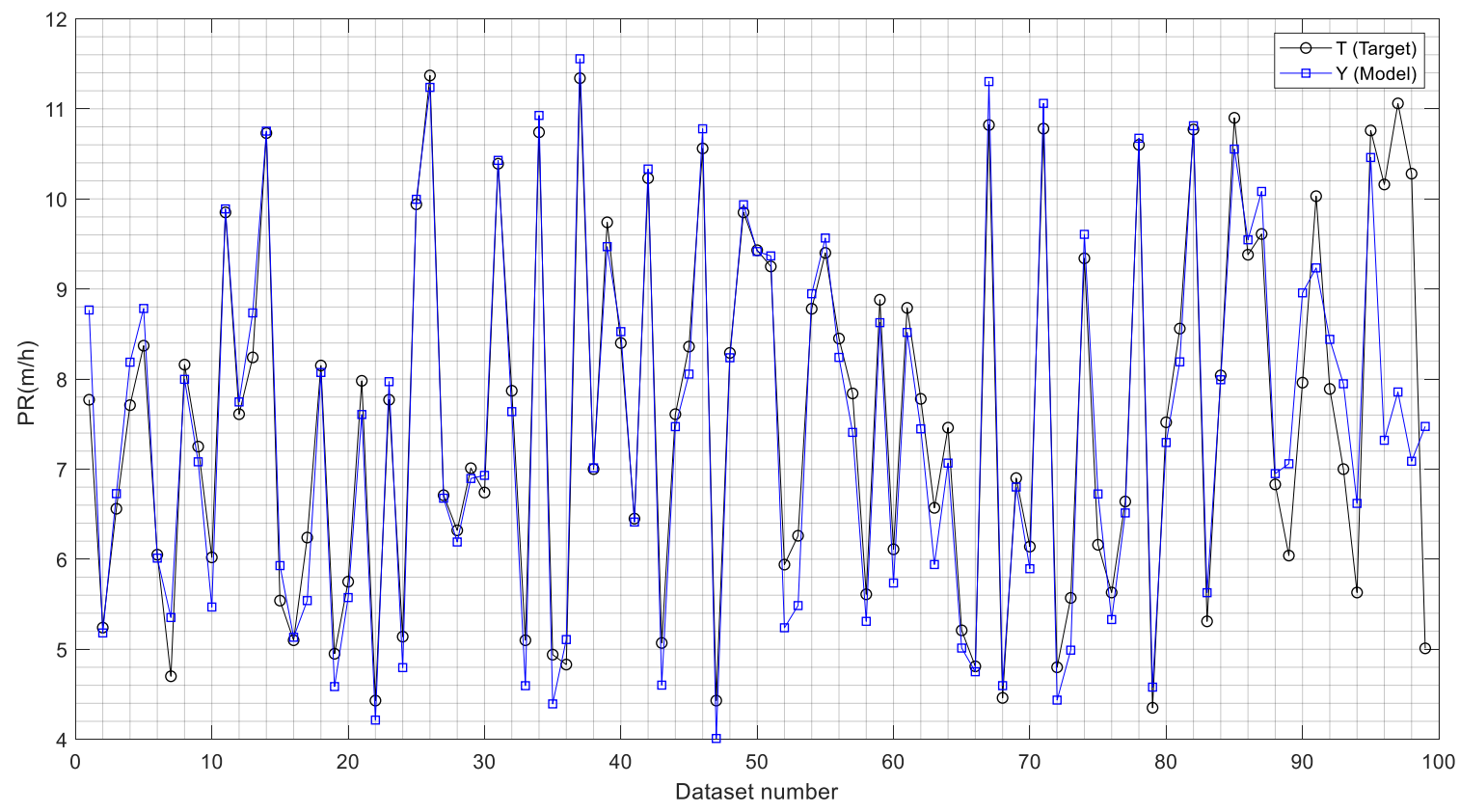

Figure 3. The matching chart of the measured values of penetration rate or target and the predicted penetration rate values by the prediction model of the top model using ACO

Table 3. Bee algorithm results for six various models

\begin{tabular}{|c|c|c|c|c|c|c|c|c|c|c|c|c|c|}
\hline \multirow[b]{2}{*}{ Model } & \multirow[b]{2}{*}{$\begin{array}{c}\text { Training } \\
\text { dataset }\end{array}$} & \multirow[b]{2}{*}{$\begin{array}{l}\text { Testing } \\
\text { dataset }\end{array}$} & \multicolumn{9}{|c|}{ Coefficient of weighting } & \multicolumn{2}{|c|}{ Model evaluation } \\
\hline & & & $\begin{array}{l}\text { W1 } \\
\text { UCS }\end{array}$ & $\begin{array}{l}\text { W2 } \\
\text { BTS }\end{array}$ & $\begin{array}{l}\text { W3 } \\
\text { RQD }\end{array}$ & $\begin{array}{c}\text { W4 } \\
\text { Cohesion }\end{array}$ & $\begin{array}{c}\text { W5 } \\
\text { Elasticity } \\
\text { modulus }\end{array}$ & $\begin{array}{c}\text { W6 } \\
\text { Poisson's } \\
\text { ratio } \\
\end{array}$ & $\begin{array}{c}\text { W7 } \\
\text { Density }\end{array}$ & $\begin{array}{c}\text { W8 } \\
\text { Joint } \\
\text { angle } \\
\end{array}$ & $\begin{array}{c}\text { W9 } \\
\text { Joint } \\
\text { spacing }\end{array}$ & $R^{2}$ & RMSE \\
\hline 1 & P2-P3-P4 & P1 & -0.0028 & 0.0319 & -0.2089 & 0.6297 & -1.9287 & 0.9532 & -2.1376 & -0.2322 & 2.9810 & 0.9020 & 0.6210 \\
\hline 2 & P1-P3-P4 & $\mathrm{P} 2$ & -0.0023 & 0.0237 & -0.3129 & 0.5209 & -1.7276 & 0.9387 & -1.7678 & -0.2934 & 2.8722 & 0.9132 & 0.5911 \\
\hline 3 & P1-P2-P4 & P3 & -0.0030 & 0.0252 & -0.3031 & 0.4696 & -1.8154 & 0.9898 & -2.3132 & -0.2111 & 2.4631 & 0.8876 & 0.6543 \\
\hline 4 & P1-P2-P3 & $\mathrm{P} 4$ & -0.0039 & 0.0251 & -0.3144 & 0.5921 & $1.9732-$ & 0.9143 & -1.9911 & -0.2987 & 2.5511 & 0.8976 & 0.6432 \\
\hline \multirow{4}{*}{5} & \multirow{4}{*}{$\begin{array}{c}100 \% \\
\text { of dataset } \\
\text { used for } \\
\text { training in } \\
\text { the model }\end{array}$} & P1 & -0.0034 & 0.0232 & -0.3198 & 0.4811 & -1.6270 & 0.9094 & -1.7612 & -0.1832 & 2.6566 & 0.8765 & 0.7654 \\
\hline & & $\mathrm{P} 2$ & -0.0034 & 0.0232 & -0.3198 & 0.4811 & -1.6270 & 0.9094 & -1.7612 & -0.1832 & 2.6566 & 0.8321 & 0.9865 \\
\hline & & P3 & -0.0034 & 0.0232 & -0.3198 & 0.4811 & -1.6270 & 0.9094 & -1.7612 & -0.1832 & 2.6566 & 0.8431 & 0.8786 \\
\hline & & P4 & -0.0034 & 0.0232 & -0.3198 & 0.4811 & -1.6270 & 0.9094 & -1.7612 & -0.1832 & 2.6566 & 0.8123 & 0.9221 \\
\hline 6 & $\begin{array}{c}85 \% \\
\text { of all } \\
\text { dataset }\end{array}$ & $\begin{array}{c}15 \% \\
\text { of all } \\
\text { dataset }\end{array}$ & -0.0025 & 0.0224 & -0.3999 & 0.3779 & -1.4186 & 0.8898 & -1.5398 & -0.2811 & 2.5497 & 0.9367 & 0.5113 \\
\hline
\end{tabular}

$P R=-0.0025 . U C S+B T S^{0.0224}-0.3999 . R Q D+C^{0.3779}-1.4186 . E+P^{0.8898}-1.5398 . D-0.2811 . J A+J S^{2.5497}$.

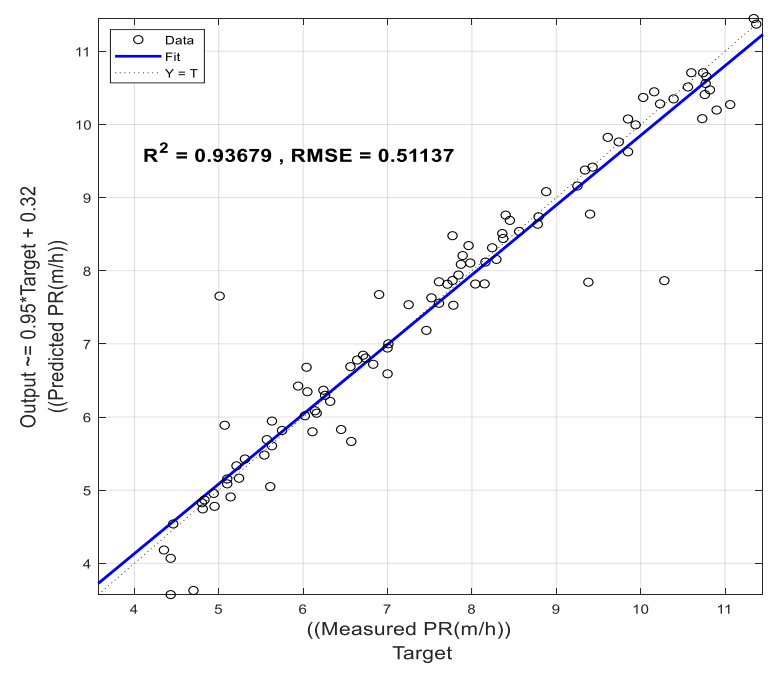

Figure 4. The distribution chart of the measured values of penetration rate or target and the predicted penetration rate values by the prediction model of the top model using $\mathrm{BCO}$
Coefficient of determination $\left(\mathrm{R}^{2}\right)$, RMSE and coefficient of weighting of the PSO algorithm for prediction of TBM penetration rate in the Sabzkooh water conveyance tunnel for all models are shown in Table 4. The distribution chart and the matching chart of the measured values of penetration rate or target and the predicted penetration rate values by the prediction model of the top model are shown in Figure 6 and 7 , respectively. Also, the equation obtained using PSO described in Equation (12).

\section{Conclusions}

Many problems are repeatedly experienced through the geotechnical assignments Such as tunnel mechanized excavating. To be able to overcome these problems, several prediction methods have been used to optimize of TBMs. One of the problems is the penetration rate prediction since it performs an important role in the costs and time scheduling of tunneling project. Penetration rate prediction can be used to reduce costs of tunneling project. 


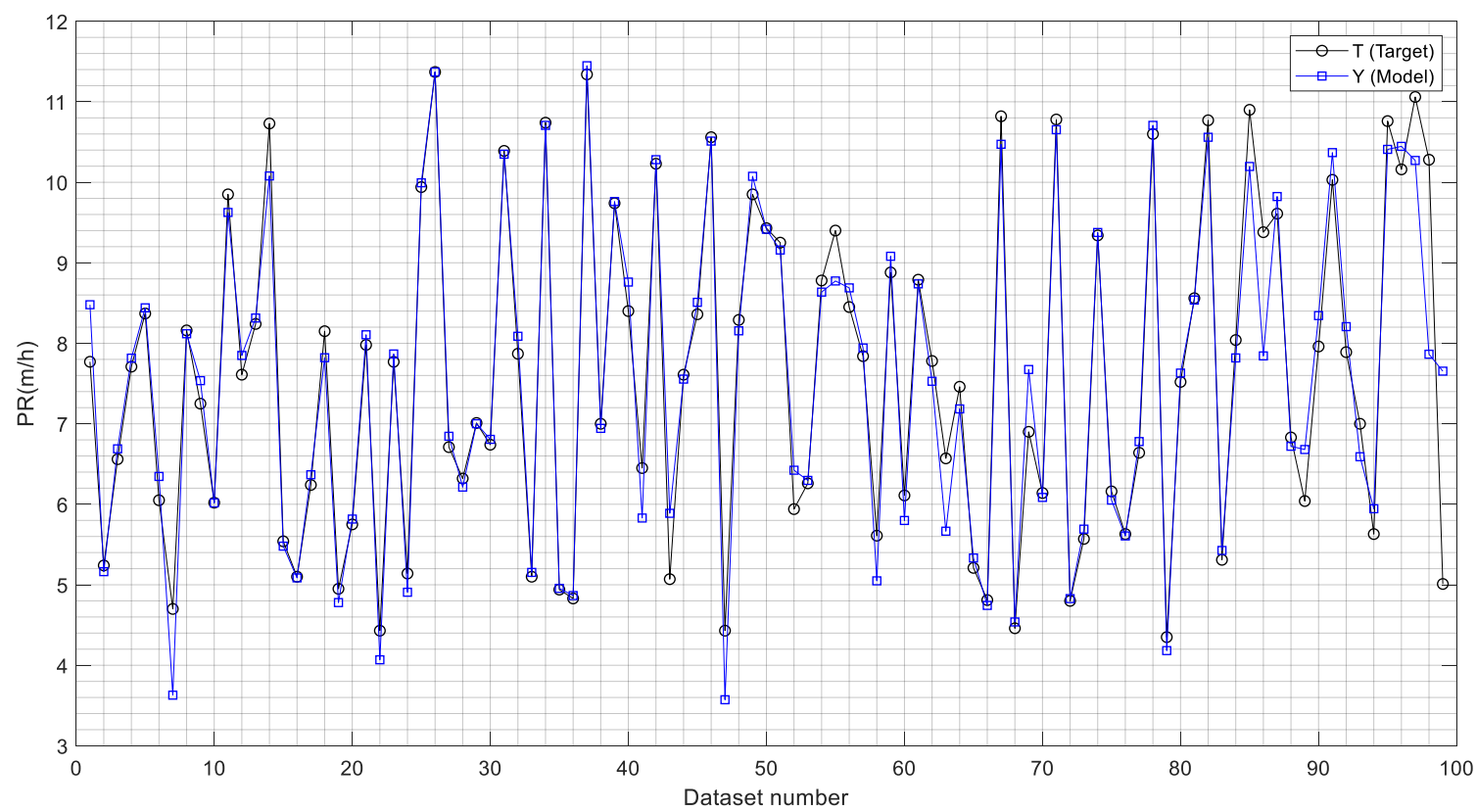

Figure 5. The matching chart of the measured values of penetration rate or target and the predicted penetration rate values by the prediction model of the top model using $\mathrm{BCO}$

Table 4. PSO algorithm results for six various models

\begin{tabular}{|c|c|c|c|c|c|c|c|c|c|c|c|c|c|}
\hline \multirow[b]{2}{*}{ Model } & \multirow[b]{2}{*}{$\begin{array}{c}\text { Training } \\
\text { dataset }\end{array}$} & \multirow[b]{2}{*}{$\begin{array}{l}\text { Testing } \\
\text { dataset }\end{array}$} & \multicolumn{9}{|c|}{ Coefficient of weighting } & \multicolumn{2}{|c|}{ Model evaluation } \\
\hline & & & $\begin{array}{l}\text { W1 } \\
\text { UCS }\end{array}$ & $\begin{array}{l}\text { W2 } \\
\text { BTS }\end{array}$ & $\begin{array}{l}\text { W3 } \\
\text { RQD }\end{array}$ & $\begin{array}{c}\text { W4 } \\
\text { Cohesion }\end{array}$ & $\begin{array}{c}\text { W5 } \\
\text { Elasticity } \\
\text { modulus }\end{array}$ & $\begin{array}{c}\text { W6 } \\
\text { Poisson's } \\
\text { ratio }\end{array}$ & $\begin{array}{c}\text { W7 } \\
\text { Density }\end{array}$ & $\begin{array}{c}\text { W8 } \\
\text { Joint } \\
\text { angle }\end{array}$ & $\begin{array}{c}\text { W9 } \\
\text { Joint } \\
\text { spacing }\end{array}$ & $R^{2}$ & RMSE \\
\hline 1 & $\mathrm{P}$ & $\mathrm{P}$ & -0.00 & 73 & 2011 & 8 & -1.9211 & 0.9587 & -2 & -0.2309 & 2.9799 & 0.8976 & 9125 \\
\hline 2 & 24 & $\mathrm{P}$ & -0.0023 & 0.0237 & -0.3110 & 0.5267 & -1.7210 & 0.9376 & -1.7611 & -0.2912 & 2.8764 & 0.9345 & 0.6532 \\
\hline 3 & & $\mathrm{P}$ & 00 & 促 & -0.3( & 0.4 & .8112 & 0.9865 & 9 & -0.2199 & 2.4699 & 0.9 & 0.5321 \\
\hline 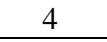 & P3 & $\mathrm{P} 4$ & -0.0039 & 0.0282 & -0.3121 & 0.5997 & 1.9710- & 0.9122 & -1.9 & -0.2912 & 2.5588 & 0.9322 & 0.5876 \\
\hline & \multirow{4}{*}{$\begin{array}{l}100 \% \\
\text { of dataset } \\
\text { used for } \\
\text { training in } \\
\text { the model }\end{array}$} & P1 & -0.0034 & 0.0265 & -0.3145 & 0.4876 & -1.6221 & 0.9011 & -1.7688 & -0.1801 & 2.6599 & 0.9567 & 0.4987 \\
\hline & & P2 & -0.0034 & 0.0265 & -0.3145 & 0.4876 & -1.6221 & 0.9011 & -1.7688 & -0.1801 & 2.6599 & 0.9087 & 0.8976 \\
\hline & & P3 & -0.0034 & 0.0265 & -0.3145 & 0.4876 & -1.6221 & 0.9011 & -1.7688 & -0.1801 & 2.6599 & 0.9123 & 0.7965 \\
\hline & & P4 & -0.0034 & 0.0265 & -0.3145 & 0.4876 & -1.6221 & 0.9011 & -1.7688 & -0.1801 & 2.6599 & 0.9211 & 0.7896 \\
\hline 6 & $\begin{array}{c}85 \% \\
\text { of all } \\
\text { dataset }\end{array}$ & $\begin{array}{c}15 \% \\
\text { of all } \\
\text { dataset }\end{array}$ & -0.0025 & כ & 6 & 8 & -1.4119 & 0.8810 & -1 & -0.2802 & 2.5422 & 0.9717 & 0.3418 \\
\hline
\end{tabular}

$P R=-0.0025 . U C S+B T S^{0.0255}-0.3956 . R Q D+C^{0.3798}-1.4119 . E+P^{0.8810}-1.5306 . D-0.2802 . J A+J S^{2.5422}$.

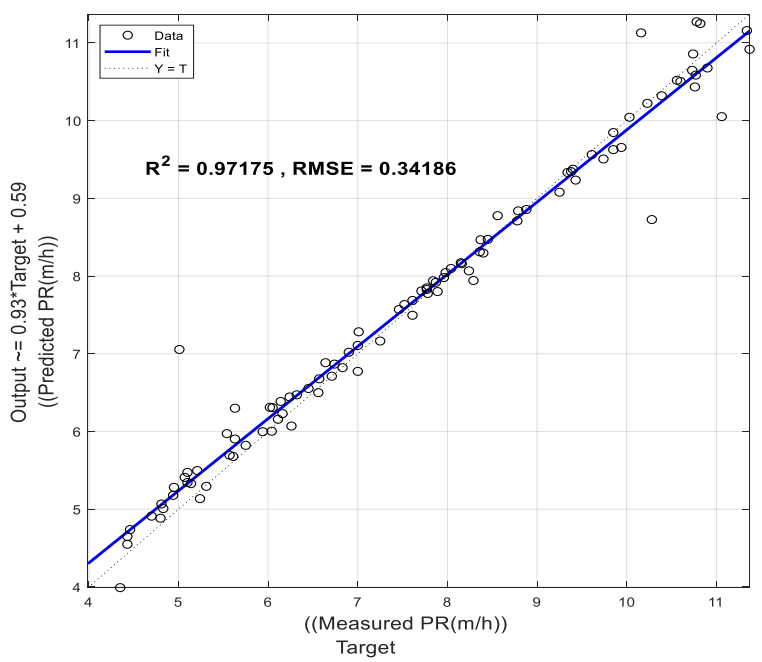

Figure 6. The distribution chart of the measured values of penetration rate or target and the predicted penetration rate values by the prediction model of the top model using PSO
In this research, field data including rock properties and the measured penetration rate of TBMs are presented using ant algorithm, bee algorithm and PSO algorithm in the Sabzkooh water conveyance tunnel. In this study, the ant algorithm, bee algorithm and PSO algorithm have been utilized for predicting TBM penetration rate in the Sabzkooh water conveyance tunnel.

Parameters including UCS (MPa), BTS (MPa), RQD (\%), cohesion $(\mathrm{MPa})$, elasticity modulus $(\mathrm{GPa})$, Poisson's ratio, density $\left(\mathrm{g} / \mathrm{cm}^{3}\right)$, joint angle (deg.), joint spacing $(\mathrm{m})$ have significant effect on the penetration rate. Six ant, bee and PSO models were generated using the improved dataset in various ways.

In models 1-4 for all three algorithms, the generated dataset is separated into 4 steps, and then each step is employed to test targets while the other steps are employed to train sets. In model 5, 100\% of the dataset was employed to train and then each step of the dataset (P1-P4) was employed for testing for the various models. 


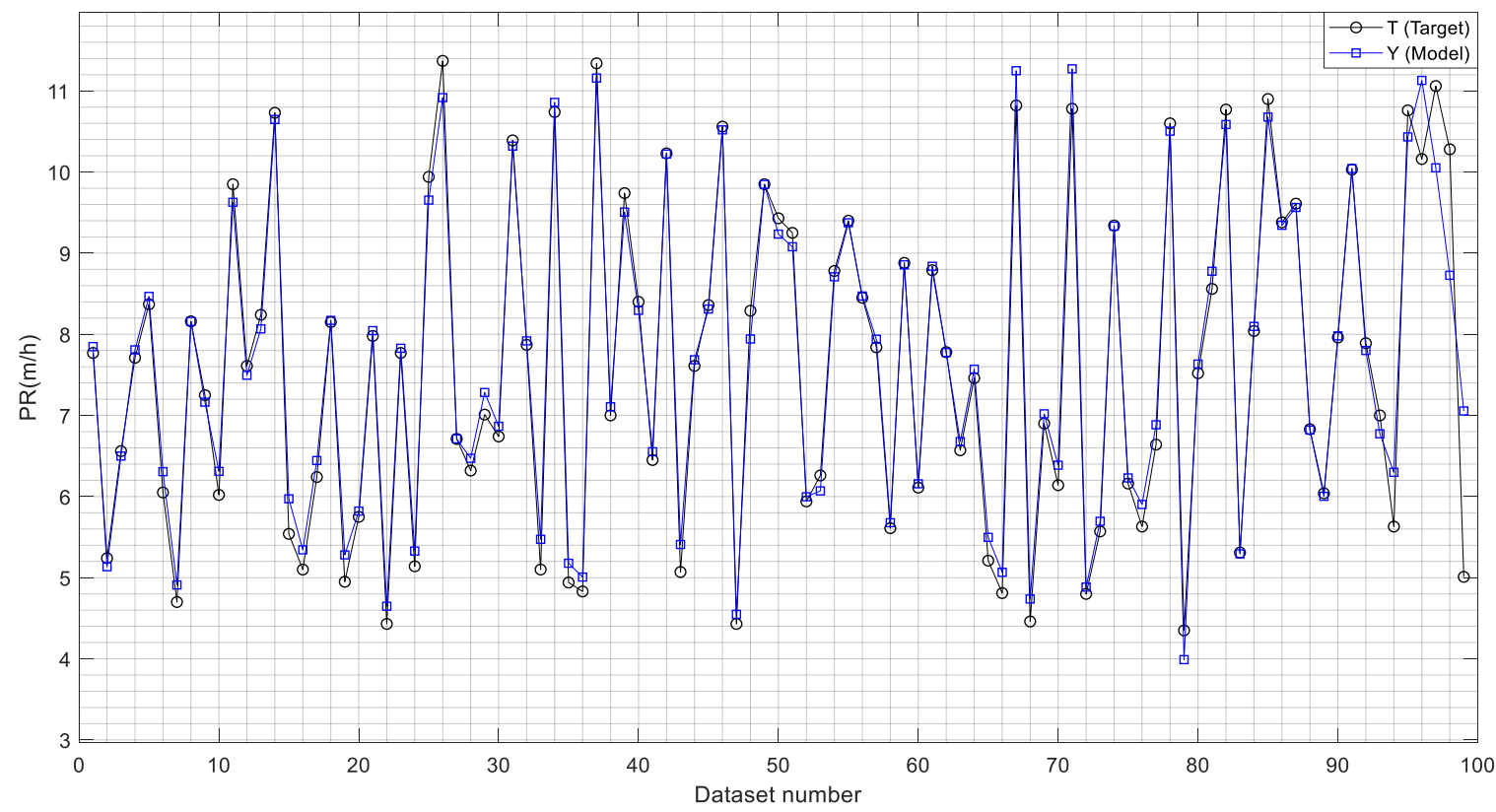

Figure 7. The matching chart of the measured values of penetration rate or target and the predicted penetration rate values by the prediction model of the top model using PSO

Finally, model 6 was improved using $85 \%$ of training dataset and $15 \%$ of testing dataset for all three algorithms. Our result is that model 6 and its attained equation are sufficient accurate, since the prediction of penetration rate for $\mathrm{ACO}$ is $R^{2}=0.8830$ and $\mathrm{RMSE}=0.6955 ; \mathrm{BCO}$ is $R^{2}=0.9367$ and $\mathrm{RMSE}=0.5113$ and PSO is $R^{2}=0.9717$ and $\mathrm{RMSE}=0.3418$, meaning that the results acceptable for using to prediction of TBM penetration rate. Also, the results showed that PSO algorithm has a tangible advantage over other algorithms.

\section{Acknowledgements}

The authors would like to thank the anonymous reviewers and editor for their valuable comments.

\section{References}

[1] Adoko, A.C., Gokceoglu, C., \& Yagiz, S. (2017). Bayesian prediction of TBM penetration rate in rock mass. Engineering Geology, (226), 245-256. https://doi.org/10.1016/j.enggeo.2017.06.014

[2] Afrasiabi, N., Rafiee, R., \& Noroozi, M. (2019). Investigating the effect of discontinuity geometrical parameters on the TBM performance in hard rock. Tunnelling and Underground Space Technology, (84), 326-333. https://doi.org/10.1016/j.tust.2018.11.039

[3] Yin, L.J., Gong, Q.M., \& Zhao, J. (2014). Study on rock mass boreability by TBM penetration test under different in situ stress conditions. Tunnelling and Underground Space Technology, (43), 413-425. https://doi.org/10.1016/j.tust.2014.06.002

[4] Armaghani, D.J., Koopialipoor, M., Marto, A., \& Yagiz, S. (2019). Application of several optimization techniques for estimating TBM advance rate in granitic rocks. Journal of Rock Mechanics and Geotechnical Engineering, 11(4), 779-789. https://doi.org/10.1016/j.jrmge.2019.01.002

[5] Armaghani, D.J., Mohamad, E.T., Narayanasamy, M.S., Narita, N., \& Yagiz, S. (2017). Development of hybrid intelligent models for predicting TBM penetration rate in hard rock condition. Tunnelling and Underground Space Technology, (63), 29-43. https://doi.org/10.1016/j.tust.2016.12.009

[6] Armetti, G., Migliazza, M.R., Ferrari, F., Berti, A., \& Padovese, P. (2018). Geological and mechanical rock mass conditions for TBM performance prediction. The case of "La Maddalena" exploratory tunnel, Chiomonte (Italy). Tunnelling and Underground Space Technology, (77), 115-126. https://doi.org/10.1016/j.tust.2018.02.012

[7] Bieniawski von Preinl, Z.T., Celada Tamames, B., Galera Fernández, J.M., \& Álvarez Hernández, M. (2006). Rock mass excavability indicator:
New way to selecting the optimum tunnel construction method. Tunnelling and Underground Space Technology, 21(3-4), 237. https://doi.org/10.1016/j.tust.2005.12.016

[8] Cassinelli, F., Cina, S., \& Innaurato, N. (1983). Power consumption and metal wear in tunnel-boring machines: analysis of tunnel-boring operation in hard rock. International Journal of Rock Mechanics and Mining Sciences \& Geomechanics Abstracts, 20(1), A25. https://doi.org/10.1016/0148-9062(83)91823-5

[9] Copur, H., Aydin, H., Bilgin, N., Balci, C., Tumac, D., \& Dayanc, C. (2014). Predicting performance of EPB TBMs by using a stochastic model implemented into a deterministic model. Tunnelling and Underground Space Technology, (42), 1-14. https://doi.org/10.1016/j.tust.2014.01.006

[10] Delisio, A., \& Zhao, J. (2014). A new model for TBM performance prediction in blocky rock conditions. Tunnelling and Underground Space Technology, (43), 440-452. https://doi.org/10.1016/j.tust.2014.06.004

[11] Delisio, A., Zhao, J., \& Einstein, H.H. (2013). Analysis and prediction of TBM performance in blocky rock conditions at the Lötschberg Base Tunnel. Tunnelling and Underground Space Technology, (33), 131-142. https://doi.org/10.1016/j.tust.2012.06.015

[12] Dudt, J.-P., \& Delisio, A. (2016). The "penalty factors" method for the prediction of TBM performances in changing grounds. Tunnelling and Underground Space Technology, (57), 195-200. https://doi.org/10.1016/j.tust.2016.01.006

[13] Zhao, Ye, Wang, T., Qin, W., \& Zhang, X. (2019). Improved raoblackwellised particle filter based on randomly weighted PSO. Cognitive Internet of Things: Frameworks, Tools and Applications, 19-29. https://doi.org/10.1007/978-3-030-04946-1_3

[14] Zare, S., Bruland, A., \& Rostami, J. (2016). Evaluating D \& B and TBM tunnelling using NTNU prediction models. Tunnelling and Underground Space Technology, (59), 55-64. https://doi.org/10.1016/j.tust.2016.06.012

[15] Zhang, J., Feng, J., Chen, G., \& Yang, X. (2019). Artificial bee colony algorithm combined with uniform design. Advances in Intelligent Information Hiding and Multimedia Signal Processing, 47-56. https://doi.org/10.1007/978-981-13-9710-3 5

[16] Hassanpour, J., Rostami, J., Khamehchiyan, M., \& Bruland, A. (2009). Developing new equations for TBM performance prediction in carbonate-argillaceous rocks: a case history of Nowsood water conveyance tunnel. Geomechanics and Geoengineering, 4(4), 287-297. https://doi.org/10.1080/17486020903174303

[17] Hassanpour, J., Rostami, J., \& Zhao, J. (2011). A new hard rock TBM performance prediction model for project planning. Tunnelling and Underground Space Technology, 26(5), 595-603. https://doi.org/10.1016/j.tust.2011.04.004

[18] Ge, Y., Wang, J., \& Li, K. (2013). Prediction of hard rock TBM penetration rate using least square support vector machine. IFAC Proceedings Volumes, 46(13), 347-352. https://doi.org/10.3182/20130708-3CN-2036.00105 
[19] Hedayatzadeh, M., \& Khademi Hamidi, J. (2014). Use of rock mass fabric index in fuzzy environment for TBM performance prediction. Engineering Geology for Society and Territory, (6), 1019-1022. https://doi.org/10.1007/978-3-319-09060-3 185

[20] Fatemi, S. A., Ahmadi, M., \& Rostami, J. (2016). Evaluation of TBM performance prediction models and sensitivity analysis of input parameters. Bulletin of Engineering Geology and the Environment, 77(2), 501-513. https://doi.org/10.1007/s10064-016-0967-2

[21] Fattahi, H., \& Moradi, A. (2016). Risk assessment and estimation of TBM penetration rate using RES-based model. Geotechnical and Geological Engineering, 35(1), 365-376. https://doi.org/10.1007/s10706016-0111-X

[22] Hassanpour, J., Ghaedi Vanani, A.A., Rostami, J., \& Cheshomi, A. (2016). Evaluation of common TBM performance prediction models based on field data from the second lot of Zagros water conveyance tunnel (ZWCT2). Tunnelling and Underground Space Technology, (52), 147-156. https://doi.org/10.1016/j.tust.2015.12.006

[23] Heydari, S., Khademi Hamidi, J., Monjezi, M., \& Eftekhari, A. (2019). An investigation of the relationship between muck geometry, TBM performance, and operational parameters: A case study in Golab II water transfer tunnel. Tunnelling and Underground Space Technology, (88), 73-86. https://doi.org/10.1016/j.tust.2018.11.043

[24] Khademi Hamidi, J., Shahriar, K., Rezai, B., \& Rostami, J. (2010). Performance prediction of hard rock TBM using Rock Mass Rating (RMR) system. Tunnelling and Underground Space Technology, 25(4), 333-345. https://doi.org/10.1016/i.tust.2010.01.008

[25] Macias, F.J., Jakobsen, P.D., Seo, Y., \& Bruland, A. (2014). Influence of rock mass fracturing on the net penetration rates of hard rock TBMs. Tunnelling and Underground Space Technology, (44), 108-120. https://doi.org/10.1016/j.tust.2014.07.009

[26] Mahdevari, S., Shirzad Haghighat, H., \& Torabi, S. R. (2013). A dynamically approach based on SVM algorithm for prediction of tunnel convergence during excavation. Tunnelling and Underground Space Technology, (38), 59-68. https://doi.org/10.1016/j.tust.2013.05.002

[27] Ma, H., Gong, Q., Wang, J., Yin, L., \& Zhao, X. (2016). Study on the influence of confining stress on TBM performance in granite rock by linear cutting test. Tunnelling and Underground Space Technology, (57), 145-150. https://doi.org/10.1016/j.tust.2016.02.020

[28] Liu, Q., Liu, J., Pan, Y., Kong, X., \& Hong, K. (2017). A case study of TBM performance prediction using a Chinese rock mass classification system - Hydropower Classification (HC) method. Tunnelling and Underground Space Technology, (65), 140-154. https://doi.org/10.1016/j.tust.2017.03.002

[29] Lee, H.-L., Sung, W.-S., \& Song, K.-I. (2018). Comparison between various multiple linear regression model for prediction of TBM performance. Sustainable Civil Infrastructures, 225-233. https://doi.org/10.1007/978-3-319-95753-1 18

[30] Salimi, A., Rostami, J., \& Moormann, C. (2019). Application of rock mass classification systems for performance estimation of rock TBMs using regression tree and artificial intelligence algorithms. Tunnelling and Underground Space Technology, (92), 103046. https://doi.org/10.1016/j.tust.2019.103046

[31] Wilfing, L., Käsling, H., \& Thuro, K. (2014). Towards a uniform definition of rock toughness for penetration prediction in TBM tunneling. Engineering Geology for Society and Territory, (6), 469-473. https://doi.org/10.1007/978-3-319-09060-3 82

[32] Namli, M., \& Bilgin, N. (2017). A model to predict daily advance rates of EPB-TBMs in a complex geology in Istanbul. Tunnelling and Underground Space Technology, (62), 43-52. https://doi.org/10.1016/j.tust.2016.11.008

[33] Tóth, Á., Gong, Q., \& Zhao, J. (2013). Case studies of TBM tunneling performance in rock-soil interface mixed ground. Tunnelling and Underground Space Technology, (38), 140-150. https://doi.org/10.1016/j.tust.2013.06.001

[34] Salimi, A., Faradonbeh, R. S., Monjezi, M., \& Moormann, C. (2016). TBM performance estimation using a classification and regression tree (CART) technique. Bulletin of Engineering Geology and the Environment, 77(1), 429-440. https://doi.org/10.1007/s10064-016-0969-0

[35] Rostami, J. (2016). Performance prediction of hard rock Tunnel Boring Machines (TBMs) in difficult ground. Tunnelling and Underground Space Technology, (57), 173-182. https://doi.org/10.1016/j.tust.2016.01.009

[36] Yagiz, S., Gokceoglu, C., Sezer, E., \& Iplikci, S. (2009). Application of two non-linear prediction tools to the estimation of tunnel boring machine performance. Engineering Applications of Artificial Intelligence, 22(4-5), 808-814. https://doi.org/10.1016/i.engappai.2009.03.007

[37] Yagiz, S. (2008). Utilizing rock mass properties for predicting TBM performance in hard rock condition. Tunnelling and Underground Space Technology, 23(3), 326-339. https://doi.org/10.1016/j.tust.2007.04.011
[38] Yagiz, S., Ghasemi, E., \& Adoko, A.C. (2018). Prediction of rock brittleness using genetic algorithm and particle swarm optimization techniques. Geotechnical and Geological Engineering, 36(6), 37673777. https://doi.org/10.1007/s10706-018-0570-3

[39] Rasouli Maleki, M. (2018). Rock Joint Rate (RJR); a new method for performance prediction of tunnel boring machines (TBMs) in hard rocks. Tunnelling and Underground Space Technology, (73), 261-286. https://doi.org/10.1016/j.tust.2017.12.022

[40] Vergara, I.M., \& Saroglou, C. (2017). Prediction of TBM performance in mixed-face ground conditions. Tunnelling and Underground Space Technology, (69), 116-124. https://doi.org/10.1016/j.tust.2017.06.015

[41] Yagiz, S., \& Karahan, H. (2011). Prediction of hard rock TBM penetration rate using particle swarm optimization. International Journal of Rock Mechanics and Mining Sciences, 48(3), 427-433. https://doi.org/10.1016/j.ijrmms.2011.02.013

[42] Yagiz, S., \& Karahan, H. (2015). Application of various optimization techniques and comparison of their performances for predicting TBM penetration rate in rock mass. International Journal of Rock Mechanics and Mining Sciences, (80), 308-315. https://doi.org/10.1016/j.ijrmms.2015.09.019

[43] Roeva, O., \& Fidanova, S. (2019). Different inter criteria analysis of variants of ACO algorithm for wireless sensor network positioning. Recent Advances in Computational Optimization, 83-103. https://doi.org/10.1007/978-3-030-22723-4_6

[44] Fang, L., Yang, Q., \& Yang, T. (2019). Research on path planning algorithm of two-machine cooperative wall climbing and sanding robot based on ant colony algorithm. Lecture Notes in Electrical Engineering, 501-511. https://doi.org/10.1007/978-981-32-9437-0 52

[45] Fidanova, S., Roeva, O., Luque, G., \& Paprzycki, M. (2019). Inter criteria analysis of different hybrid ant colony optimization algorithms for workforce planning. Recent Advances in Computational Optimization, 61-81. https://doi.org/10.1007/978-3-030-22723-4_5

[46] Mirjalili, S., Song Dong, J., \& Lewis, A. (2019). Ant colony optimizer: theory, literature review, and application in AUV path planning. Nature-Inspired Optimizers, 7-21. https://doi.org/10.1007/978-3-03012127-3_2

[47] Sushma, M.B., Roy, S., Prasad, M.B.R., \& Maji, A. (2019). Optimum point of intersection selection in horizontal highway alignment design: a comparative study using path planner method and ant algorithm. Transportation Research, 185-199. https://doi.org/10.1007/978-98132-9042-6 15

[48] Preetha, P.S., \& Kusagur, A. (2019). Implementation of ant-lion optimization algorithm in energy management problem and comparison. Learning and Analytics in Intelligent Systems, 462-469. https://doi.org/10.1007/978-3-030-24318-0 55

[49] Zhang, X.X. (2019). Research on logistics distribution routing optimization based on ant colony algorithm. Proceedings of the Sixth International Forum on Decision Sciences, 65-78. https://doi.org/10.1007/978981-13-8229-1_7

[50] Niranjani, G., \& Umamaheswari, K. (2019). Modified DFA minimization with artificial bee colony optimization in vehicular routing problem with time windows. Data Management, Analytics and Innovation, 643-662. https://doi.org/10.1007/978-981-32-9949-8_45

[51] Demircan, C., Keçebaş, A., \& Bayrakçı, H.C. (2019). Artificial bee colony-based GMPPT for non-homogeneous operating conditions in a bifacial CPVT system. Modern Maximum Power Point Tracking Techniques for Photovoltaic Energy Systems, 331-353. https://doi.org/10.1007/978-3-030-05578-3_12

[52] Uysal, F., Kilinc, E., Kurt, H., Celik, E., Dugenci, M., \& Sagiroglu, S. (2017). Estimating see beck coefficient of a p-type high temperature thermoelectric material using bee algorithm multi-layer perception. Journal of Electronic Materials, 46(8), 4931-4938. https://doi.org/10.1007/s11664-017-5497-6

[53] Pawar, P.J., \& Khalkar, M.Y. (2019). Multi-objective optimization of wire-electric discharge machining process using multi-objective artificial bee colony algorithm. Advanced Engineering Optimization Through Intelligent Techniques, 39-46. https://doi.org/10.1007/978981-13-8196-6_4

[54] Pattanayak, S., \& Choudhury, B.B. (2019). An effective trajectory planning for a material handling robot using PSO algorithm. Advances in Intelligent Systems and Computing, 73-81. https://doi.org/10.1007/978-981-13-8676-3_7

[55] Sahu, S., \& Choudhury, B.B. (2019). PSO based path planning of a sixaxis industrial robot. Advances in Intelligent Systems and Computing, 213-220. https://doi.org/10.1007/978-981-13-8676-3 19

[56] Saremi, S., \& Mirjalili, S. (2019). Evaluating PSO and MOPSO equipped with evolutionary population dynamics. Algorithms for Intelligent Systems, 61-88. https://doi.org/10.1007/978-981-13-9757-8_4 
[57] Subhra Pal, S., Hira, R., \& Pal, S. (2019). Comparison of four nature inspired clustering algorithms: PSO, GSA, BH and IWD. Computational Intelligence in Pattern Recognition, 669-674. https://doi.org/10.1007/978-981-13-9042-5 57

[58] Yadav, A.S., Swami, A., Ahlawat, N., Bhatt, D., \& Kher, G. (2019). Electronic components' supply chain management of electronic industrial development for warehouse and its impact on the environment using particle swarm optimization algorithm. Asset Analytics, 427-443. https://doi.org/10.1007/978-981-13-9698-4 23
[59] Yao, S., Jiang, X., \& Wei, X. (2019). A model for job-shop scheduling based on NN-PSO technique. Advances in Intelligent Systems and Computing, 344-350. https://doi.org/10.1007/978-3-030-14680-1 38

[60] Zhao, Yu, Gong, Q., Tian, Z., Zhou, S., \& Jiang, H. (2019). Torque fluctuation analysis and penetration prediction of EPB TBM in rocksoil interface mixed ground. Tunnelling and Underground Space Technology, (91), 103002. https://doi.org/10.1016/j.tust.2019.103002

Прогнозування швидкості проходки тунелепрохідницького комбайна за допомогою мурашиного алгоритму оптимізації, бджолиного алгоритму оптимізації та оптимізації методом рою частинок (на прикладі водостічного тунелю Sabzkooh, Iран)

\section{А. Афраді, А. Ебрахімабаді, Т. Халладжян}

Мета. Створення нового підходу до прогнозу та оцінки швидкості проходки тунелепрохідного комбайна (ТПК) в умовах різних порід на основі використання специфічних методів оптимізації.

Методика. Методи дослідження включають мурашиний алгоритм оптимізації (МАО), бджолиний алгоритм оптимізації (БАО) i оптимізацію методом рою частинок (ОМРЧ). Створена велика база даних з продуктивності комбайна із використанням швидкості проходки в якості вихідного параметра, а також таких вхідних параметрів непорушеної породи і породного масиву, як міцність на стиск (ПС) (МПа), міцність на розтяг, яка вимірюється “бразильським тестом” (БПР) (МПа), показник якості грунту (ПКГ) (\%), зв’язність грунту (МПа), модуль пружності (ГПа), коефіцієнт Пуассона, щільність (г/см³), кут стикування (град.) та відстань між швами (м).

Результати. Виконано аналіз в ході дослідження, який дозволив створити кілька надійних реалістичних моделей для прогнозування швидкості проходки ТПК. Модель, побудована на МАО, має коефіцієнт детермінації $R^{2}=0.88$ і корінь із середнього квадрата відхилення RMSE $=0.69$, БАО-моделі $-R^{2}=0.93$ і RMSE $=0.51$, та ОМРЧ-моделі $-R^{2}=0.97 \mathrm{i} \operatorname{RMSE}=0.34$.

Наукова новизна. Вперше прогнозувалася швидкість проходки ТПК із використанням вищеописаних методів на прикладі водостічного тунелю Sabzkooh.

Практична значимість. Результати дослідження є цінними для проектування в тонелебудівництві. Запропоновані нові підходи виявилися вельми ефективними, проте ОМРЧ алгоритм дозволяє отримати більш точні і реалістичні дані.

Ключові слова: тунелепрохідницький комбайн, швидкість проходки, водостічний тунель Sabzkoоh, мурашиний алгоритм оптимізації, бджсолиний алгоритм оптимізаиії та оптимізаиія методом рою частинок

\section{Прогнозирование скорости проходки туннелепроходческого комбайна с помощью муравьиного алгоритма оптимизации, пчелиного алгоритма оптимизации и оптимизации методом роя частиц (на примере водосточного туннеля Sabzkooh, Иран)}

\section{А. Афради, А. Эбрахимабади, Т. Халладжян}

Цель. Создание нового подхода к прогнозу и оценке скорости проходки туннелепроходческого комбайна (ТПК) в условиях различных пород на основе использования специфических методов оптимизации.

Методика. Методы исследования включают муравьиный алгоритм оптимизации (МАО), пчелиный алгоритм оптимизации (ПАО) и оптимизацию методом роя частиц (ОМРЧ). Создана обширная база данных по производительности комбайна с использованием скорости проходки в качестве выходного параметра, а также таких входных параметров ненарушенной породы и породного массива, как прочность на сжатие (ПС) (МПа), прочность на растяжение, измеряемая “бразильским тестом" (БПР) (МПа), показатель качества грунта (ПКГ) (\%), связность грунта (МПа), модуль упругости (ГПа), коэффициент Пуассона, плотность (г/см³), угол стыковки (град.) и расстояние между швами (м).

Результаты. Выполнен анализ в ходе исследования, который позволил создать несколько надежных реалистичных моделей для прогнозирования скорости проходки ТПК. Модель, построенная на МАО, имеет коэффициент детерминации $R^{2}=0.88$ и корень из среднего квадрата отклонения RMSE $=0.69$, ПАО-модели $-R^{2}=0.93$ и RMSE $=0.51$, и ОМРЧ-модели $-R^{2}=0.97$ и $\mathrm{RMSE}=0.34$.

Научная новизна. Впервые прогнозировалась скорость проходки ТПК с использованием вышеописанных методов на примере водосточного туннеля Sabzkooh.

Практическая значимость. Результаты исследования являются ценными для проектирования в тоннелестроении. Предложенные новые подходы оказались весьма эффективны, однако ОМРЧ алгоритм позволяет получить более точные и реалистичные данные.

Ключевые слова: туннелепроходческий комбайн, скорость проходки, водосточный туннель Sabzkооһ, муравьиный алгоритм оптимизачии, пчелиный алгоритм оптимизации и оптимизация методом роя частии

\section{Article info}

Received: 4 January 2020

Accepted: 17 April 2020

Available online: 18 April 2020 